NBER WORKING PAPER SERIES

EXCHANGE RATES AND PRICES

Rudiger Dornbusch

Working Paper No. 1769

NATIONAL BUREAU OF ECONOMIC RESEARCH

1050 Massachusetts Avenue

Cambridge, MA 02138

December 1985

The research reported here is part of the NBER's research program in International Studies and project in Productivity and Industrial Change in the World Economy. Any opinions expressed are those of the author and not those of the National Bureau of Economic Research. 
NBER Working Paper \#1769

Decenber 1985

Exchange Rates and Prices

\begin{abstract}
The appreciation of the U.S. dollar over the past five years opens important areas of research. The fact of a large and persistent real appreciation poses a challenge for equilibriun theorists to uncover the change in fundamentals and seems to supprt the role of long-term wage contracts in macroeconomic adjustment. This paper adopts the perspective of given wages and investigates in a partial equilibrium setting the determinants of relative price changes of different groups of goods. Specifically it advances hypotheses about those sectors where an exchange rate change should lead to large relative price changes and others where the relative price effects should be negligible.

The general idea is to draw on models of industrial organization to explain price adjustments in terms of the degree of market concentration. the extent of product homogeneity and substitutability, and the relative market shares of domestic and foreign firms. The exchange rate movement and the less than fully flexible money wage interact to produce a cost shock for some firms in an industry - foreign firms in the home market and home firms abroad-- and thus bring about the need for an industry-wide adjustment in prices.
\end{abstract}

Rudiger Dombusch

M.I.T.

E52-357

Cambridge, MA 02139 
Revised

October 1985

\title{
EXCHANGE RATES AND PRICES
}

\author{
Rudiger Dornbusch \\ Massachusetts Institute of Technology
}

The appreclation of the U.S. dollar over the past five years opens important areas of research. The fact of a large and persistent real appreciation poses a challenge for equilibriut theorists to uncover the change In fundamentals. For those who explain medium-term macroeconomics in terms of Fischer-Taylor long-term wage contracts the episode provides a striking example of the differential speeds of adjustment of wages, goods and assets prices. This paper adopts the latter perspective and explains the determinants of relative price changes of different groups of goods. specifically it advances hypotheses about those sectors where an exchange rate change should lead to large relative price changes and others where the relative price effects should be negligible.

The general idea is to draw on nodels of Industrial organization to explain price adjustments in terms of the degree of market concentration. the extent of product homogeneity and substitutability, and the relative market shares of domestic and foreign firms. Modeis of industrial organization have, of course, been very fruitfuily applied in trade theory: their application to macro-pricing issues, however, has been surprisingly

*I am indebted to Olivier Blanchard. Stan Fischer, Paul Krugman, Julio Rotemberg, Larry Summers and Jean Tirole for helpfui suggestions. An earlier version of this paper was presented at the NBER summer workshop and the NBER Heeting on Business Fluctuations and $I$ wish to acknowledge helpful comments received on those accastons. David Wilcox provided valuable research ass is tance. 
slow.1 There is a long-standing questioning of PPP, especially in the work of Kravis and Lipsey $(1978,1983)$. But so far there seems to exist no formal analysis of price setting behavior in this context. 2

This paper adopts a partial equilibrium approach in that it assumes throughout a given, exogeneous movement in the nominal exchange rate. The exchange rate movement and the less than fully flexible money wage interact to produce a cost shock for some firms in an industry -- foreign firms in the home market and home firms abroad-- and thus bring about the need for an industry-wide adjustment in prices. Although the assumption of exogeneous exchange rate movements and sticky wages is open to criticism, it is a useful working hypothesis for the purpose of investigating relative price is sues.

The first section reviews some facts. Section 2 offers a stylized view of the link between exchange rates and prices. The third and fourth sections study respectively the behavior of meterials prices and manufactures.

\section{Some Facts}

The large dollar appreciation is reflected both in absolute and relative prices. Table 1 shows two measures of the change in U.S. relative costs and prices: relative unit labor costs and the relative value added

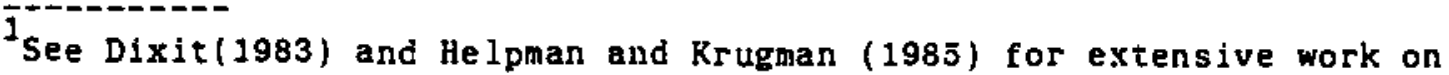
and references to trade applications. In the macro context see Blanchard (1985). Hart (1982) and Monkiw (1985). Aizenman (1984,1985) and Giovannini (1985) investigate price setting behavior in the context of exchange rate movements. Their focus. however, is on short-term issues of transactions costs and uncertainty rather than on the large, persistent movements in the real exchange rate.
} 
deflator in manufacturing. In each case the U.S. series is deflated by the corresponding time series for the trade-weighted average in dollars of our trading partners. The magnitude of the change in relative costs and prices arises from the fact that unit labor costs and prices abroad in national currencies were rising at a lower rate than in the U.S. and that the dollar, rather than of fetting the divergent trend by a depreciation, further reinforced that divergence by a strong appreciation.

Table 1 Relative Costs and Prices in Manufacturing (Cumulative Percentage Change)

$\begin{array}{lcc} & 1976-80 & 1980-84 \\ \text { Relative Unft Labor Costs } & -8.0 & 44.0 \\ \text { Relative Value Added Deflator } & -14.7 & 35.6\end{array}$

Source: International Financial Statistics

Figure 1 shows absolute prices measured by the U.S. GNP deflator and the deflators for imports and exports. Prfor to 1980, import prices increase more rapidy than the deflator and, to a lesser extent, so do export prices. During this period the dollar was deperciating. Afte: 1S 30 . however, the dollar appreciation gets underway, and inport price increases slow down and ultimately import prices fall in absolute terms. Export prices track the GDP delator more closely though the pattern of divergences is similar to that for imports. At this broad level it is clear then that import prices fell relative to the deflator and relative to export prices. 
Figure 1

THE U.S. DEFLATORS FOR GNP, IMPORTS AND EXPORTS

(Index 1979:I =100)

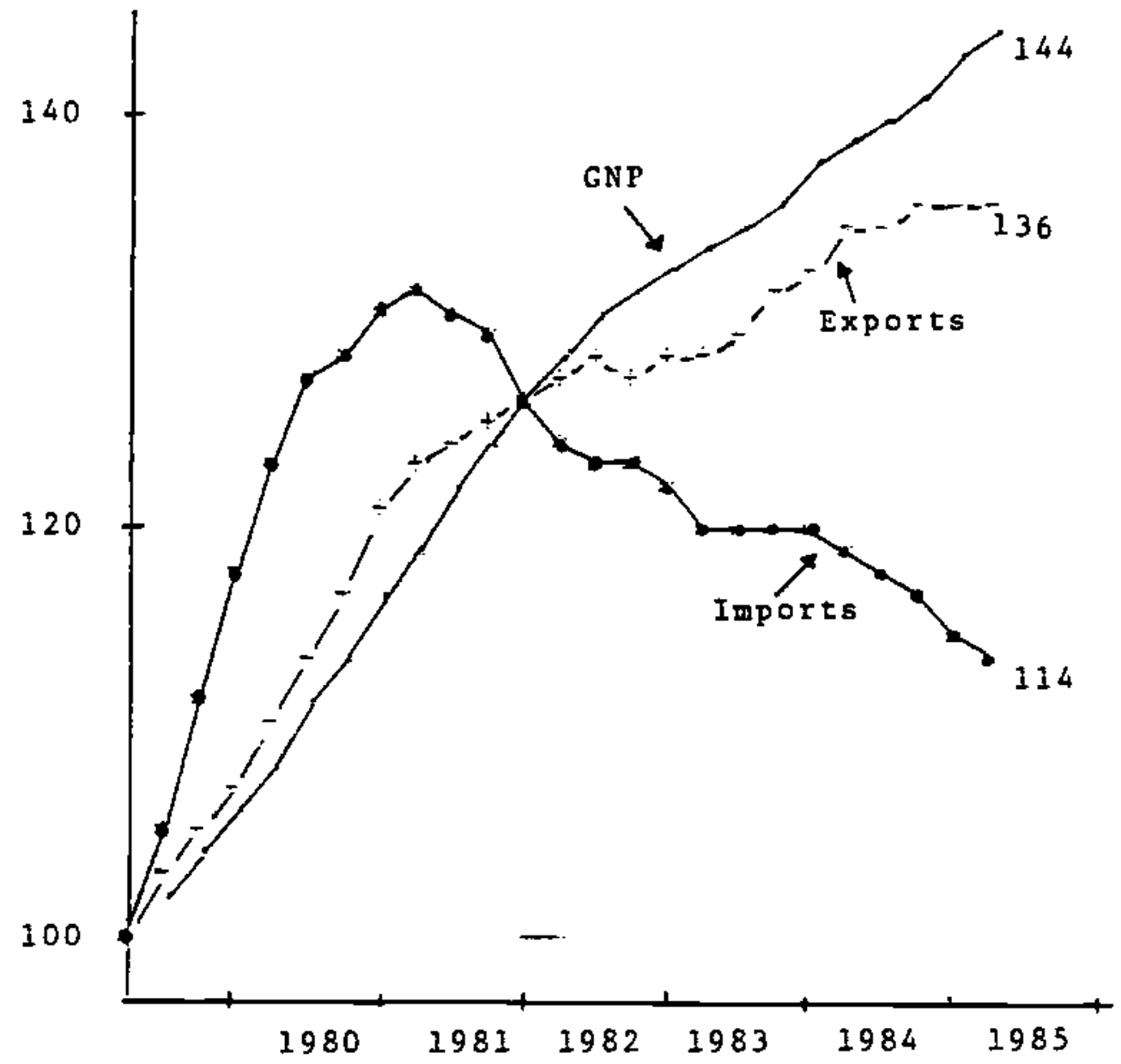


In the absence of comprehensive price series Table 2 shows unit values for different export and import groups. The table shows that the absolute decline in import prices must be attributed to the first three groups, and not to finished manufactures. 0il price Increases in 1979 easily explain the divergent pattern of export and import unit values for crude materials. The interesting comparison therefore is between the relatively homogenous conmodity groups--food and semi-manufactures-- and finished manufactures where price setting and product differentiation are likely to be important. For the former group export and import unit values move roughly in line, whlle for finished manufactures exports follow the domestic price trend and imports show a much smaller of an increase.

Table 2 Unit Values of Imports and Exports (Index 1980:1=100)

\begin{tabular}{|c|c|c|c|c|c|c|c|c|}
\hline & \multicolumn{2}{|c|}{ Foods } & \multicolumn{2}{|c|}{ Materials } & \multicolumn{2}{|c|}{ Semi-Manufactures } & \multirow{2}{*}{$\begin{array}{c}\text { Finished } \\
E\end{array}$} & \multirow{2}{*}{$\underset{M}{\text { Manufactures }}$} \\
\hline & $E$ & $\mathbf{M}$ & $E$ & $\mathbf{M}$ & $E$ & $\mathbf{M}$ & & \\
\hline $1979: 2$ & 87 & 82 & 92 & 60 & 71 & 77 & 95 & 91 \\
\hline $1980: 1$ & 100 & 100 & 100 & 100 & 100 & 100 & 100 & 100 \\
\hline $1985: 1$ & 94 & 87 & 91 & 97 & 86 & 82 & 139 & 106 \\
\hline
\end{tabular}

Note: $E=E x p o r t s, \quad M=I m p o r t s$

We urn now to models of price determination for commodities and for manufactures to explain these patterns.

\section{Standard Yode1s}

There are two extreme models that have been studied extensively in the literature. One assumes that the "law of one price" holds. Prices of 
goods are geographically arbitraged and, adjusted for tariffs and transport costs, they are equalized in different locations. Homogeneity, information and perfect competition assure this result. ${ }^{3}$ Let $p_{i}, p^{*}{ }_{i}$ and $e$ denote the price of good $i$ in the home country and currency, the foreign price, and the home currency price of foreign exchange. Arbitrage then implies:

$$
p_{i}=e_{* i}
$$

In this form, or in the first-difference version of Gustav Cassel, the law of one price is asserted in the PPP literature. The law of one price has seen important application in the monetary approach to exchange rates which combines the quantity theory of money, price flexibility, and PPP to obtain a theory of the exchange rate. An important implication of complete spatial arbitrage, not only for commodities but for all goods, is the idea that relative national price levels in a common currency are independent of the exchange rate since exchange rate movements merely reflect, passively, divergent national price trends. That is. of course, an application of the homogeneity postulate which holds when money is fully neutral.

The alternative model might be called "Keynesian". Here it is assumed that each country is fully specialized in the production of "its own" good. Domestic and foreign goods are less than fully homogeneous or substitutable. Wages are fixed in national currencies or at least sticky.

Letting $P$ and $P *$ be the national GDP deflators, the relative price of domestic and foreign goods or the real exchange rate then is:

\footnotetext{
3 For a review of PPP see Dornbusch $(1985)$.
} 


$$
\lambda=\mathrm{P} / \mathrm{eP}^{*}
$$

If the mark-up of prices over unit labor costs is constant then for given unit labor costs prices will be given. Hence in this model, exchange rate movements change relative prices one-for-one. Exchange rate-induced changes in the relative price affect the world distribution of demand and employment. This approach tends to be used in open economy versions of the IS-LM model in the Meade-Mundell tradition.

In what follows we show that equation (1) would be a useful model of international price relations for materials--say sisal, copper, tea-whereas (2) more nearly describes what happens with manufactures. But the assumption of a constant mark-up is no longer justified when domestic and foreign firms have strategic interactions in their pricing.

\section{Materials Prices}

In this section we consider the prices of commodities. To be specific we discuss the IMF indices of metals and agricultural raw materials as concrete examples. We make the point that movements in the real exchange rate between the dollar and other currencies will affect the real prices of comnodities in terms of the U.S. GNP deflator. Put alternatively, given the U.S. GNP deflator a real appreciation of the dollar will reduce world commodity prices in dollars.

Consider a simple model of the world market for a connodity. There are two regions, the U.S. and the rest of the world. The rest of the world 
is viewed as the foreign country and denoted by an asterix. World demand for commodities depends on the real price of commodities in terms of GNP deflators in the two reglons and on real activity. The supply of commodities is assumed exogeneous.

$$
S=D(p / P . Y)+D^{*}\left(P^{*} / P^{*} . Y^{*}\right)
$$

where

$$
\begin{aligned}
& Y, Y^{*} \text { are domestic and foreign activity } \\
& p, P^{*} \text { are conmodity prices in home and foreign currency } \\
& P, P^{*} \text { - the national deflators }
\end{aligned}
$$

Now it is assumed that materials or commodity prices are arbitraged so that $p=e p^{*}$.

Using that relation in (3), and the definition of the real exchange rate $\lambda \equiv$ P/eP*, we can solve for the real commodity price of the U.S. in terms of activity, commodity supply and the real exchange rate:

$$
p / P=J\left(Y, Y^{*}, \lambda ; S\right)
$$

The model is illustrated in Figure 2. The schedule MN shows the commodity market equilibrium for given levels of activity and a given supply. It has a negative slope since an increase in the real price to users in one region reduces demand; in order to restore market equilibrium there must be an offsetting cut in the real price for the other region. Note that the real price is always measured in terms of the respective regions' GNP 
deflators. The ray $O R$ has a slope equal to $P / P^{*}$. Equilibrium obtains initially at point $A$.

The model confirms the well-established cyclical behavior of real comnodity prices: an increase in activity raises real commodity prices. But there is also a role for the real exchange rate: equation (4) shows that a real appreclation of the U.S. will lower real commodity prices in terms of the U.S. deflator while raising them in terms of foreign deflators. ${ }^{4}$ In terms of Figure 2 the ray $O R$ rotates to $O R^{\prime}$ as a result of the real appreclation and the equilibriun shifts to point B. Thls effect is simply the implication of a flextble price model for commodities combined with an assumed change in the real exchange rate. The latter assumption implies that real commodity prices, in terms of the respective users' deflators, must change because the law of one price does hold for comnodities but not for def lators.

The elasticity of the real commodity price with respect to the real exchange rate is determined by the elasticities of demand of the two regions weighted by their shares in commodity absorption. The model does have the implication that the elasticity should be less than one. With equal demand elasticities the fraction reduces to the U.S. share in world commodity absorption .

The model was tested with guarterly data for agricultural raw materials and for metals over the period 1970-85:1. The real price of each commodity group in terms of the t.S. deflator was regressed on a distributed lag of the U.S. real exchange rate and on world industrial produrtion. ${ }^{5}$ The regession is run in the $\log$ difference of the variables.

\footnotetext{
4 The effect of exchange rates on real commodity prices is discussed in Dornbusch $(1983,1984)$ and Sachs $(1984,1985)$.

The real exchange rate is measured by the IMF's relative value added deflator and world economic activity is the IMF index of industrial production for the main industrlal countries.
} 


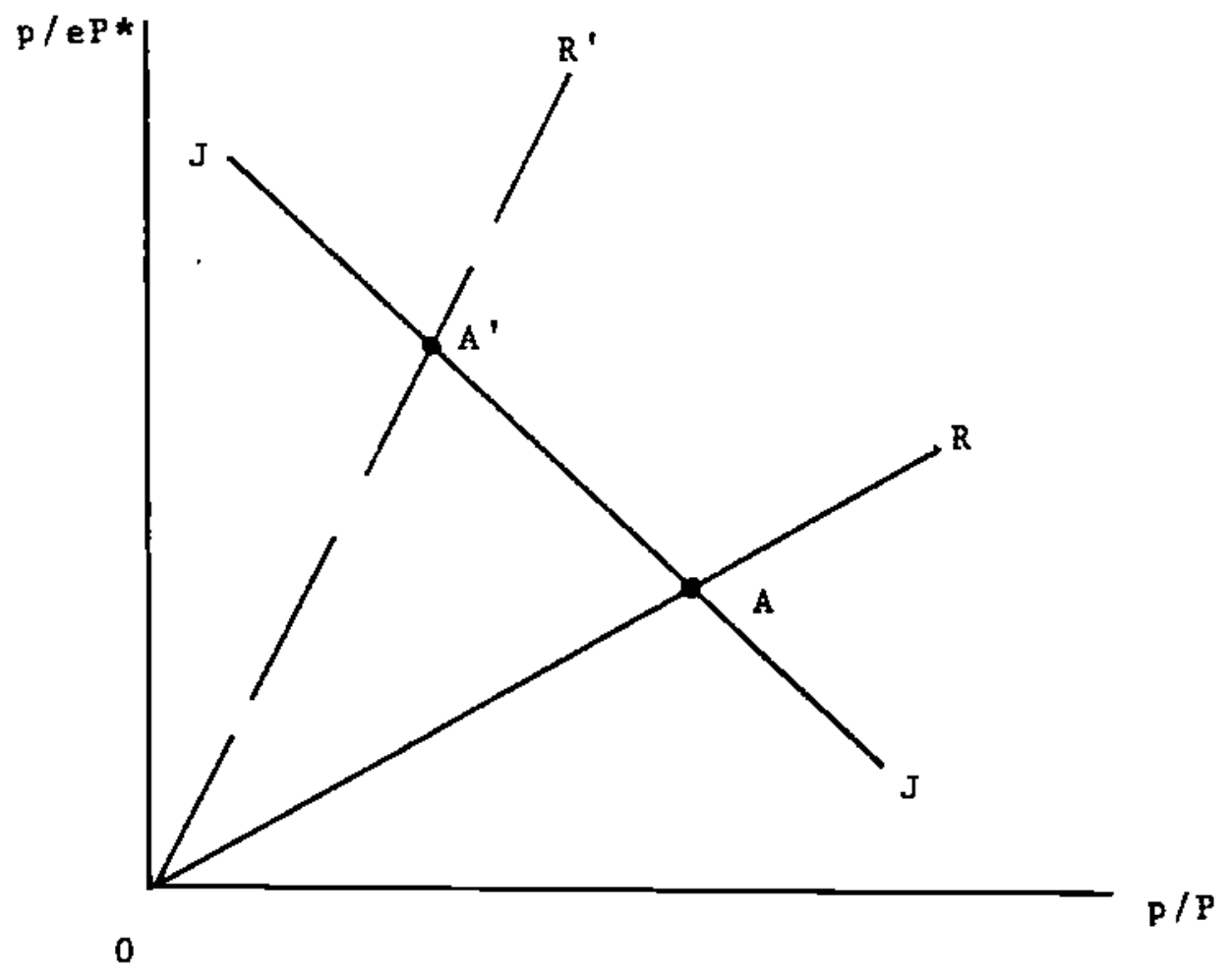

Figure 2

The Real Price of Commodities 
Table 3 The Effect of Real Exchange Ratea on Commodity Prices:1970:1-1985:1

\begin{tabular}{lccccc} 
& Constant & Activity & Real Exchange Rate & Rho $\mathrm{R}^{2}$ & $\mathrm{D}-\mathrm{W}$ \\
\hline Metals & -1.99 & 0.94 & -1.44 & 0.18 & 0.301 .97 \\
& $(-1.72)$ & $(2.17)$ & $(-2.42)$ & & \\
Agricultural & & & & \\
Materials & -1.73 & 2.67 & -1.22 & & \\
& $(-1.69)$ & $(3.51)$ & $(-2.77)$ & & \\
\end{tabular}

Note: t-statistics in parenthesis

Both activity and the real exchange rate appear as significant determinants of changes in the real comrodity price. The real exchange rate has the anticlpated sign, but the quantative effect is far larger than the model predicts. Recall that the coefficient should be a negative fraction, perhaps -0.5 , but certainly not larger than unity in absolute value.

There are a number of possible explanations for seeming the overreaction to real exchange rates apparent in Table 3 . Perhaps the most likely reason for the result is the neglect of structural change and supply side effects including inventories. But conmodity markets (unlike the markets for manufactures) operate in the manner asset markets and hence an emphasis on interest rates and a distinction between anticipated and unanticipated movements in the determinants of demand is also appropriate.

\section{Manufactures}

Table 1 gave evidence of large, persistent fluctuations in exchange rate-adjusted relative prices in manufacturing. In this section we explore theoretical models that would explain these price movements as the result of changes in relative unit labor costs. 
The basic assumption we make is that firms in any industry have a Iinear technology, with labor as the only input. Lnit labor costs, $w$ and $w^{* *}$, are given in home and foreign currency respectively. This assumption about costs is combined with a model of pricing to yield predictions about the behavior of relative prices. The experiment is simply this: the exchange rate change, say a dollar appreciation, lowers foreign unit labor costs in dollars. As a result the market equilibrium is disturbed in each industry and price and output adjustments must occur. What these adjustments look like depends on three factors: ${ }^{6}$

- Market integration or separation. Is a particular commodity is traded in an integrated world market, or are there significant barriers to restrict spatial arbitrage?

- Substitution between domestic and foreign variants of a product. The extent of substitution influences price setting and the output effects of cost and price changes.

- Market organisation. Is the market perfectly competitive in which case forms are price takers, or is the market imperfectly competitive or oligopolistic in which case firms are price setters and may interact in strategic ways?

Two models lend themselves in a straight forward fashion to formulating the price response to cost shocks of part of the industry. The Cournot model assumes perfect substitution between alternative suppliers and places more emphas is on the extent of oligopoly. It allows in principle more variation

\footnotetext{
${ }_{A}$ f ourth item of relevance is the functional form of the demand
} curve. 
In the mark-up in response to cost shocks and thus has the potential for a richer pattern of response to cost shocks. The Dixit-Stiglitz (1977) nodel by contrast emphasizes imperfect substitution between alternative suppliers and in Its predictions looks very much like the "Keyneslan" model discussed above. An alternative to the Dixit-Stiglitz nodel, again emphasizing product differentiation, is the Salop model of competition of competition on a circle.

The Cournot Mode 1:

In the Cournot formulation the analytical focus is on a homogeneous commodity sold in an oligopolistic market. Each seller assumes that other sellers defend their sales volume. We assume that there is an effective spatial separation between the home market and foreign markets and discuss the pricing in the U.S. market.

Market denand is linear in the price of the commodity:

$$
D=a-b p
$$

where all non-price determinants are captured in the constant. There are $n$ domestic suppliers and $n^{*}$ foreign firms with respective sales of $q$ and $q^{*}$ per firm respectively. Aggregate sales of these firms have to sum to market demand :

$$
D=n q+n * q *
$$


Each firm maximizes profits taking the sales of other firms as given. Profits of the representative domestic and foreign firm in the home market are:

$$
\begin{aligned}
& \pi_{i}=(p-w)\left[a-b p-(n-1) q-n^{*} q^{*}\right] \\
& \pi_{j}=\left(p / e-w^{*}\right)\left[a-b p-n q-\left(n^{*}-1\right) q^{*}\right]
\end{aligned}
$$

Maximization gives rise to the reaction functions shown in Figure 3. The home country's reaction function is $J J$ while $J * J *$ represents the foreign country. They yield the ocournot-e Nash equllibrium shown at point $A$ which gives the equilibrium quantity allocation between representative domestic and foreign firms. The common equilibrium price in the industry is given by:

$$
p=(n w+n * e w) / N+a / b N \quad ; N=n+n *+1
$$

A dollar appreciation shifts the $J^{*} J^{*}$ schedule out and to the right, thus leading to increased foreign sales and reduced domestic sales. At the initial level of sales for every supplier, the individual foreign $f$ irm faces a given marginal revenue schedule in dollars but experiences a reduction in its dollar marginal cost and hence wishes to increase output. In the new equilibrlum at point $A^{\prime}$ foreign firms increase their output while home firms contract. The industry price declines, as seen from ( 8 ),

We are now interested in the exte.tt to which exchange rate movements (or movements in relative unit labor costs) affect the equilibrium price. 
The elasticity of the equilibriun price with respect to the exchange rate, 8 is :

$$
\Omega=\left(n^{*} / N\right)\left(e w^{*} / p\right)
$$

The elasticity formula has two determinants: the relative number of foreign $f$ irms (or the relative number of firms with wages not fixed in dollars), and the ratio of marginal cost to price of foreign suppliers. Since both terms are fractions it is imnediately clear from (9) that a dollar appreciation will lower price less than proportionally. The decline in the dollar price is larger the more competitive the Industry -- i.e. the smaller the mark-up of price over marginal cost-- and the larger the share of imports in total sales. This latter term is represented by $n * / N$ on the assumption of symmetry and initially equal wages between countries.

Equation (9) is interesting because it stretches all the way from the "small country" case to the case where exchange rates have virtually no impact on home pricing. The small country case, in the trade literature. is the case where a country is a price taker in world markets. In that case a currency depreciation will raise prices in the same proportion. This is, of course, the Iixiting case here under perfect competition and a number of foreign firms that is large relative to home firms.

The other extrene of no influence of the exchange rate on home prices results when there are few firms in the industry, most of which are domestic. In that case foreign firms absorb the dollar appreciation primarily in the form of extra profits rather than increased sales. 
The Cournot model thus potentially explains both unchanging prices and steep price declines. The market structure -- import share and concentration -- are the key parameters that explain the outcome.

Consider next U.S. export firms competing in a foreign mrket. A dollar appreciation will lower their marginal revenue in dollars. With unchanged marginal dollar cost these firms will contract. In terms of Figure 3 applied to the foreign market our schedule $J J$ shifts down and to the left. The common foreign currency price rises, but in dollars it declines, though less than proportionately to the appreciation. Using the same model for the foreign market we find that the elasticity of foreign price with respect to the exchange rate is:

$$
\Omega^{*}=-\left(n^{*} / N^{*}\right)\left(w / e p^{*}\right)
$$

where $n^{\prime}$ is the number of domestic firms in the foreign market and $N^{*}$ the total number of $f$ irms. With $\ell^{*}$ a negative fraction the dollar price of exports, p*e, has an elasticity $1+8^{*}$ and hence must decline in response to a dollar appreciation.

Consider next the price of i.s. exports relative to the price of imports. Remembering that the markets are separated we look at p/ep*. In case of a dollar appreciation, dollar export prices rise relative to import prices if the following condition holds: 


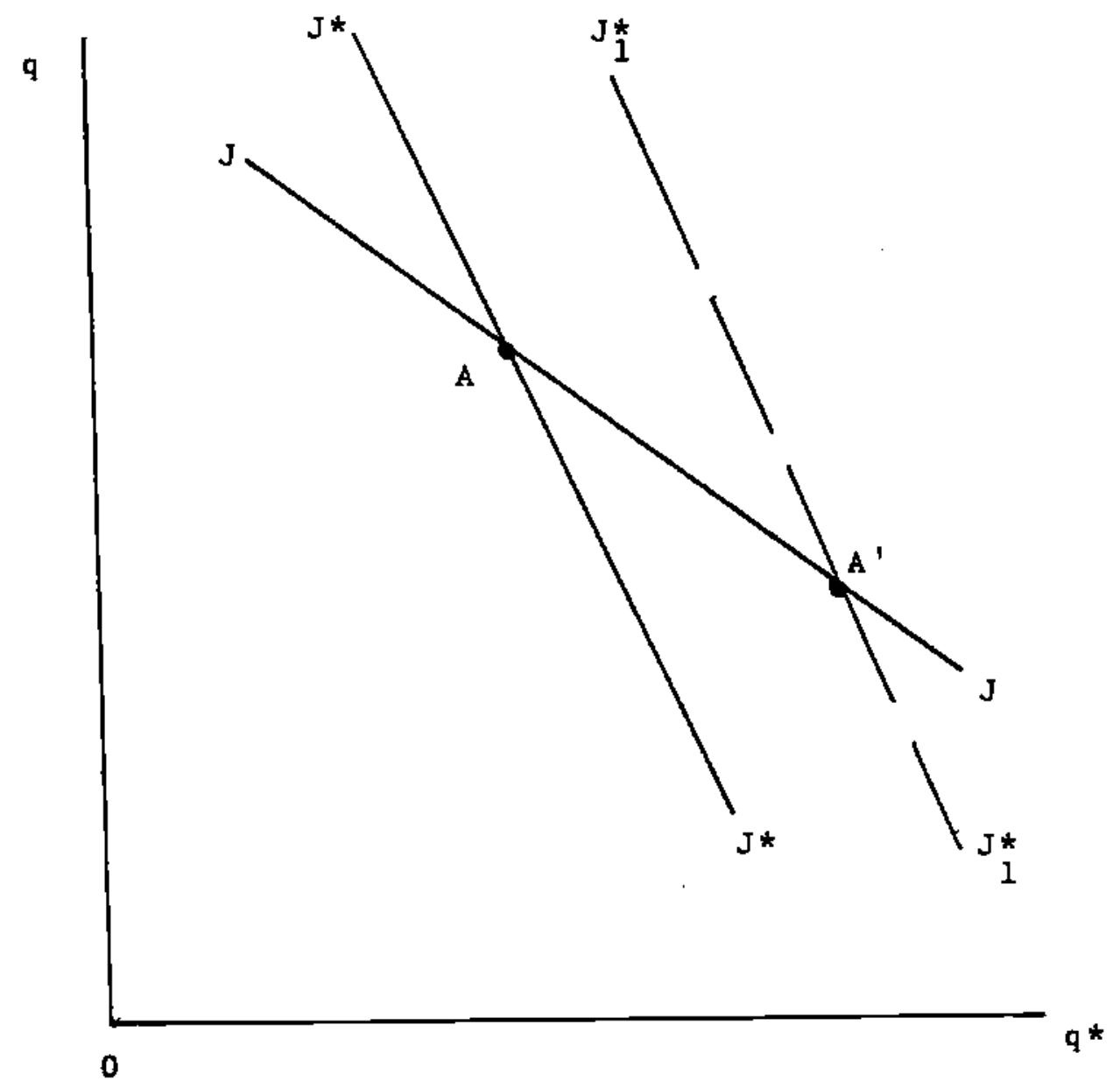

Figure 3

The Impact of Appreciation 
In princfple the condition can go either way. In the small country case export and import prices in dollars fall in the same proportion as the currency appreciates $\left(\Omega=1, Q^{*}=-1\right)$ so that the relatfve price p/ep* remains constant. In general the outcome depends on the relative oligopolistic structure of the two markets. Export prices will rise relative to import prices, in the appreciation case. If at home import competition is pervasive and foreign markets are strongly affected by U.S. suppliers as well as highly competitive. ${ }^{7}$

The Dixit-Stiglitz Model: The representative consumer in this model maximizes a utility function $V$ wfth consumption of two commodities $z$ and $x$ as arguments.

$$
\mathrm{V}=\mathrm{U}(\mathrm{z}, \mathrm{x}) ; \mathrm{x}=\left(\sum \mathrm{x}_{\mathrm{i}}\right)^{1 / \mathrm{a}} \quad 0<\mathrm{a}<1
$$

We focus on commodity $x$ which is an index of consumption of different brands of the same good. We assume that there are n domestic firms supplying some variant each, and $n *$ foreign firms doing the same.

Maximization yields the demand for each individual brand, as well as the utility-based price index for commodity $x$ :

\footnotetext{
The results are sensitive to the functional form of the demand curve. With a constant elasticity demand function $D=A p^{-B}$ the easticity of equilibrium price with respect to the exchange rate becomes $\Omega=$ $\left(n^{*} / N\right)\left(e w^{*} / W\right)$ where $N=n+n^{*}$ and $W=(n / N) w+\left(n^{*} / N\right) e w^{*}$. The exchange rate impact thus depends no longer on cost-price mark-up and, when costs are initially equal between countries, is only $z$ functicn of the relative number of $f$ irms. In that case the wage-price ratio $w / p=1-$ $1 /$ BN.
} 
(13)

$$
x_{i}=x\left(P / p_{i}\right)^{c} ; \quad c=1 /(1-a)
$$

$$
P=\left[\left(\sum p_{1}^{h}+\sum p_{j}{ }^{h}\right) /\left(n+n^{*}\right)\right]^{1 / h} ; \quad h=-a /(1-a)
$$

In (14) $p_{i}$ denotes the price of a brand produced in the home country and $p_{j}$ the price of an imported brand.

We are now interested tn the response of prices to cost shocks. The individual imperfectly competitive ftrm faces a demand curve as in (13) with the relative price of its product $p_{i} / P$ as the determinant. The firm assumes it is sufficentiy small so that its own price changes leave the industry price, $P$, unchanged. The representative firm's profjts are

$$
\pi_{i}=\left(p_{i}-w\right) x_{i}
$$

Maximization yields the familiar constant mark-up pricing equation:

$$
p_{1}=\alpha w \quad ; \quad \alpha=1 /(1-1 / c)
$$

where $\alpha$ depends inversely on the elasticity of substitution among variants. Since the industry structure is symetric each domestic form will follow the sane pricing rule with an equal mark-up.

We now assume again markets are separated and we can thus meaningfully discuss the price set by a foreign firm for our market. Foreign firms in the home market face the same form of demand curve as home firms 
and hence they also follow the same pricing rule, with the same mark-up, but with foreign wages in dollars, ew*, as the base of their pricing.

$$
p_{j}=\alpha e w^{*}
$$

From (16) and (17) we have two strong predictions: First the relative price of domestic and foreign variants in the home market depends just on relative unit labor costs in a comon currency:

$$
p_{i} / p_{j}=w / e w^{*}
$$

The industry price can be calculated and it is readily shown that the relative price of a domestic variant in terms of the industry price index $\left(p_{i} / P\right)$ is just a function of the relative wage, w/ew*. The elasticity of the relative price will be

$$
n * z /(n+n * z) \quad ; \quad z=\left(w / e w^{*}\right)^{1 / h}
$$

If wages are initially equal between countries the effect of an exchange rate change on the industry price and on the relative price depends merely on the fraction of firms that has wages fixed in foreign currency and hence experiences a reduction of their costs in dollars when the dollar appreciates.

Given the wages in home and foreign currency the Dixit-stiglitz model provides strong predictions about the impact of dollar appreciation: 
The prices of imported variants fall in proportion to the decline of dollar unit labor costs of foreign firms and the prices of domestic variants would remain unchanged.

Exporting firms at home, although they have to compete in foreign markets, still follow their mark-up pricing on dollar wages. Accordingly a change in the dollar does not affect their dollar export price. of course, it does affect their sales and profits. A dollar appreciation will raise their foreign currency price in the same proportion and hence raise their relative price in the foreign market.

The strong prediction of the model is to look for a sharp fall in import prices relative to domestic prices and to see export prices stay constant relative to domestic prices of the same variant. This is, of course, the exact specification of the 'fixed-price "Keynesian" model which is derived here as an implication of given labir costs and an invariant mark-up.

\section{An Extended Dixit Stiglitz Model:}

The Dixit-Stiglitz model represents Chamberlinian imperfect competition and hence each supplier assumes that he does not affect industry price. Strategic interaction with other firms is therefore excluded. But the same structure of differentiated products can easily be adapted to introduce strategic interaction by way of a conjectural variation. Assume, contrary to the preceding section, that the individual firm is sufficently large to affect industry price. Assume, too, that firms respond to changes in the industry price and let the conjectural variation be the parameter $\sigma$, a 
fraction between zero and one. Thus a one percentage point $r$ ise in the industry price is assumed to cause each firm to raise their price by $\sigma$ percent. Assuming a given conjectural variation rather than deriving it from a dynamic game-theoretic framework is obviously a shortcut.

With this adaptation the demand curve facing the individual firm's price policy no longer is a constant mark-up over unit labor costs but rather becomes:

$$
p_{i}=\alpha^{\prime} w \quad ; \quad \alpha^{\prime}=1 /[1-1 / c(1-\varepsilon)]
$$

where the term $E$ emerges to capture the strategic interaction between firms. The term is a function of relative prices and the conjectural variation: 8

$$
0 \leqslant \varepsilon\left(\sigma, p_{i} / p_{j}\right) \equiv\left[(1-\sigma)\left\{n+n^{*}\left(p_{j} / p_{i}\right)^{h}\right\}+\sigma\right]^{-1}<1
$$

From (18) and (19) it is clear that pricing decisions are now interdependent, so we can represent each firm's pricing policy in terms of a price reaction functions.

$$
\begin{aligned}
& p_{i}=F\left(p_{j}, \sigma, c\right) w \\
& p_{j}=F^{*}\left(p_{i}, \sigma, c\right) \text { ew* }
\end{aligned}
$$

8 The tedious derivation of (19) relies on the definition of the industry price,P, the conjectural variation and the assumption of symetry for domestic firms and for foreign firms so that we can deal with representative firms. 
Figure 4 shows the inpact of a dollar appreciation in this setting. The schedules $F F$ and $F^{*} F^{*}$ are the reaction functions and $A$ is the initial equllibrium .

An appreclation will shift the foreign reaction function up and to the left. The magnitude of the shift at constant relative prices (e.g. along the ray $O R$ ) is proportional to the appreciation. Thus $A B / B O$ represents the percentage appreciation. The new equilibrium is therefore at $A^{\prime}$. Note that this equilibrium at $A^{\prime}$ differs from the Dixit-Stiglitz one and resembles more nearly the cournot model. Foreign firms reduce their price proportionally less than the reduction in dollar unit labor costs and home firms cut their price. But at $A^{\prime}$ the relative price of domestic products has increased relative to $A$ as can be seen by the slope of a ray through $A^{\prime}$ compared to $\mathrm{OR}$.

\section{Competition on the circle:}

We conclude the discussion of masnufactures prices with a sketch of a third model of pricing for differentiated products. In the Dixit-stiglitz model consumers buy some of each brand of a product. Applied to toothpaste that is an implausible model; we should look for an alternative model where consumers buy only one brand. A particularly manageable version is the Salop (1979) model where consumers' tastes (defined by preferences for the attributes or characteristics of goods) are uniformly spread over the unit circle. Since domestic and foreign firms have potentially different costs, a symmetric equilibrium does not necessarily exist. We simplify matters by 


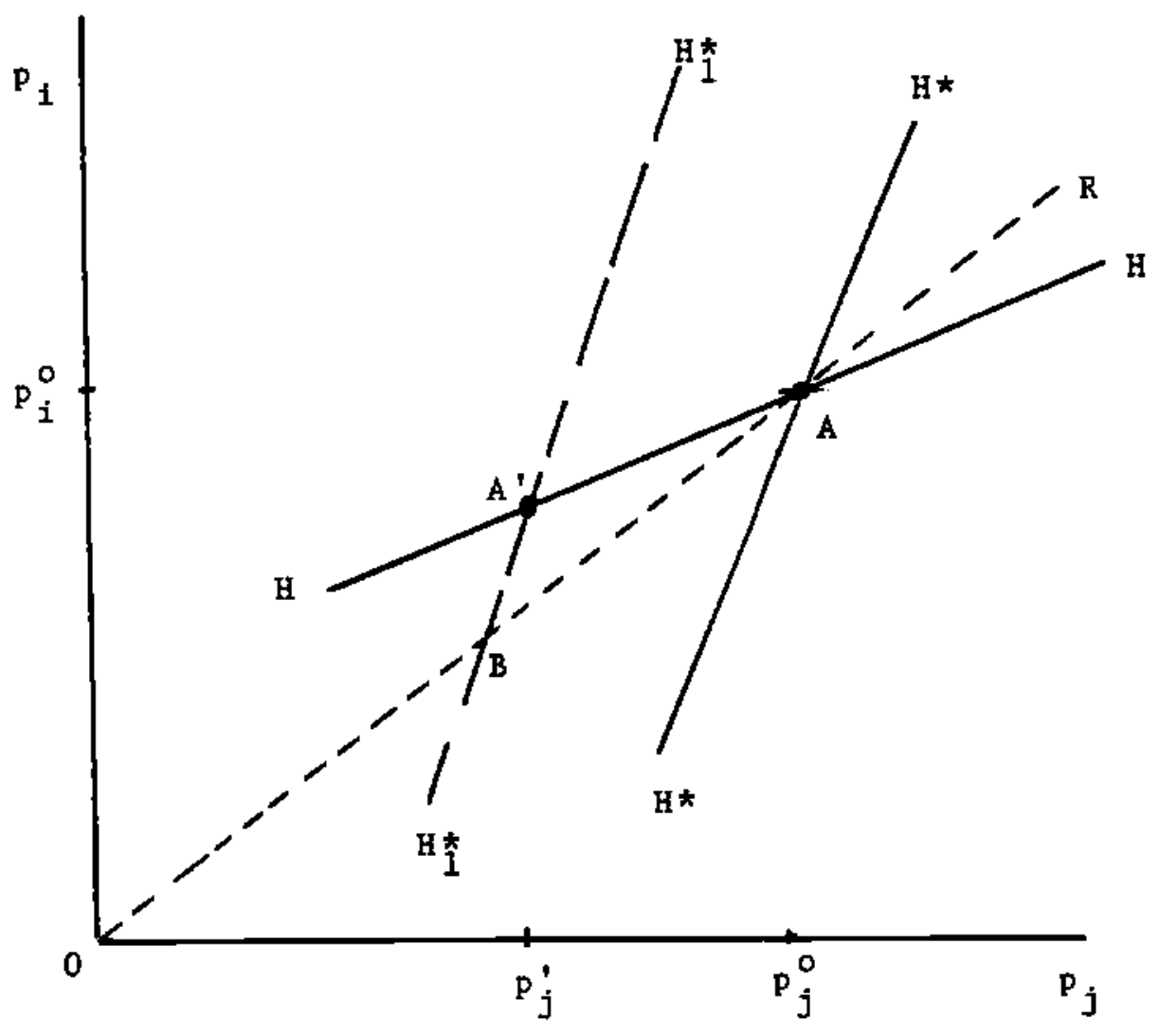

Figure 4

The Extended Dixit-Stiglitz Model 
assuming that there is an even number of firms and that domestic and foreign firms alternate along the circle and that each consumers buys a unt fron one or the other of the firms adjacent to his preferred location.

Producers have constant unit labor costs and other than entry costs there are no fixed costs. With these assumptions we can derive equilibrium prices and study the impact of dollar cost changes for foreign suppliers. Each consumer is located at a point on the circle. The significance of the location on the circle is that firms may not supply precisely the most preferred product and that accordingly the consumer is forced to chose between the alternatives of fered by the most adjacently located brands. Following salop consumer surplus derived from buylng a good that is a distance $x$ from the best location (on the circle) depends on the price and on the distance and the relationship is assumed linear:

$$
h=v-c x-p
$$

where $v$ is a constant, c denotes the utility cost per unit distance from the best location and $p$ is the price of a particular firm. Consumers will be indifferent between the brands offered by two competing firms on either side of their preferred location if the consumer surplus is the same, $h_{i}=h_{j}$. Taking the case of $\mathrm{n}$ firms that are equally spaced on the circle the condition for indifference between a domestlc and a foreign supplier is:

$$
v-c x-p^{*}=v-c(1 / n-x)-p
$$


Hence the distance served by a foreign firm is an increasing function of the price charged by domestic firms and a declining function of its own price.

(22a) $\quad x=\left(p+c / n-p^{*}\right) / 2 c$

Profits for the foreign firm are equal to 2 Lx times the excess of price over marginal cost:

$$
\pi=\left(p^{*}-e w^{*}\right) 2 L\left(p+c / n-p^{*}\right) / 2 c
$$

where $L$ denotes the total number of consumers and hence $L$ also represents the density per unit distance served by the firm. Since the firm serves both sides of its location $2 \mathrm{Lx}$ is the total number of units sold. Maximization taking domestic price as given yields the foreign reaction function:

$$
p^{*}=\left(p+c / n+e w^{*}\right) / 2
$$

The typical donestic firm's reaction function is derived in the same manner:

$$
p=\left(p^{*}+c / n+w\right) / 2
$$

From (24) and (25) we obtain the solution for the prices charged by home and foreign firms:

$$
p=c / n+\left(e w^{*}+2 w\right) / 3 ; p^{*}=c / n+\left(2 e w^{*}+w\right) / 3
$$


From (26) we can calculate the elasticity of prices with respect to the exchange rate.

$$
\omega=(1 / 3)\left(e w^{*} / p\right) ; \omega^{*}=(2 / 3)\left(e w^{*} / p^{*}\right)
$$

Note that these elasticities, once again are fractions. If wages and hence prices are initially equal, wrep*, the elasticities simplify to the following expressions:

(27a)

$$
\omega=r / 3 ; \omega^{*}=2 \gamma / 3 ; \quad r \equiv 1 /(1+\mathrm{c} / \mathrm{nw})
$$

The elasticities show that the relative price of imported goods declines and that the change in the relative price $r / 3$ is smaller the smaller the number of $\mathrm{firms}$ in the industry and the lower the substitutability as measured by the term c. Along with the change in relative prices there will be a shift in demand from home firms to foreign firms as consumers tradeoff the reduction in price for a larger distance from their most preferred brand location. 9

9 At this point it is worth commenting on the properties of the equilibrium when there is not an alternating pattern between domestic and foreign firms. Specifically suppose that there are five firms, two domestic and three adjacent foreign firms. It is apparent that the middle foreign firm conpetes only with foreign firms and hence will cut its price more than the outlying foreign firms that compete with home $f$ irms which have not experienced a cost reduction. Hence there will be three prices. 
The same model can be applied to the foreign market. In terns of foreign exchange the prices will $r$ ise and the relative price of our export brands abroad will rise. But because it rises proportlonally less than the currency appreciates, the export price in dollars changes in the proportion:

$$
\omega^{\prime}=1-2 \gamma^{*} / 3 \quad: \quad \gamma^{*}=1 /\left(1+c / n^{*} w\right)
$$

where $n^{*}$ is the total number of $f$ irms serving the foreign market. We can therefore $f$ ind the change in the relative price of domestic exports in terms of imports and in terms of home brands:

$$
\omega^{\prime}-\omega^{*}=1-2\left(\gamma+\gamma^{*}\right) / 3 \quad ; \quad \omega^{\prime}-\omega=1-2 \gamma^{*} / 3-\gamma / 3
$$

The first point to note is that export prices may rise or fall in terms of import prices as a result of appreciation. But the fewer the number of firms in each country, the more likely that an appreciation leads to a fall in the relative price of exports. By contrast as the number of $f$ irms increases (and hence $\gamma$ and $\gamma^{*}$ tend to unity) the relative price of exports must rise, reflecting the increase in the relative unit labor cost at home which sets competitive relative prices.

The second point is that export prices may decline relative to domestic prices as a result of an appreciation. This must be the case if the number of $f$ irms in the two markets is the same $\left(\gamma=\gamma^{*}\right)$. As the number of firms increases the relative price tends to remain unchanged. This result 
arises because price gets competed down to marginal cost which is the same w for home and export production. It is apparent frow (29) that the change in the relative price in terms of importables will always be larger than that in terms of domestic goods.

Summary: We have now seen common features of a number of models: they all predict that appreciation should lead to a decline in the price of imports. In the case of homogeneous goods domestic firms, of course, fully match the decline in price. If products are differentiated it will always be the case that the relative price of the imported brands declines in response to an appreciation. The extent of the decline depends on a measure of competition and on the relative number of home and foreign firms.

The empirically testable hypotheses concern price-marginal cost mark-ups and the behavior of relative prices. For differentiated products it is always the case that export and domestic prices will stay closer in line than import and domestic prices. In the Dixit-Stiglitz model imports fall in terms of domestic goods and the relative price of exports goods stays unchanged in terms of home goods. In other models the export price can in principle even decline in terms of imports.

Some Evidence: Econometric testing of the hypotheses is unfortunately precluded by the absence of a comprehensive matched data set of export. import and domestic prices. The BLS does now publish transactions prices for exports and imports that are disaggregated to the 4-digit leve] and classified on the SIC basis. But few of the series go back beyond the early 
1980 's. Where they do the revisions of the SIC-based U.S. producer prices in nost cases are either not at all available yet or only go back very few years. A complete overlap between export, import, and domestic prices for more than two years apparently only exists for fewer than a handful of cases and overlap between any two series is limited to less than a dozen.

At a more informal level there are intersting patterns to observe. First consider a comparison of U.S. export prices in dollars with those of Germany and Japan. Table 3 shows the percentage loss in U.S. competitiveness over the period 1980:IV to 1984:IV using as a sample all available data at a highly disaggregated level. In the U.S.-Germany comparison there are 36 different matched time series, in the U.S.-Japan comparison there are 20. Typical items in the list of commodities are "gears and gear units" or "household electrical space heating".

Table 3 Changes in Relative Prices: U.S. Versus Germany and Japan (Percentage Change in Relative Export Prices:1980:IV-1984:IV)

$\begin{array}{lcc} & \text { U.S. -Germany } & \text { U.S. -Japan } \\ \text { Mean } & 39.3 & 24.9 \\ \text { Standard Deviation } & 6.1 & 8.3\end{array}$

Source:BLS, unpublished data

The data do not allow us to tell whether these are prices of the same products sold in the same third market (say france) or whether they represent exports to different markets (say U.S. sales to France and German sales in the U.S.). Accordingly we cannot tell from these data whether they reflect market segmentation or imperfect substitution. They are consistent 
with markets being segmented but goods being perfect substitutes and having a common price in the same narket independent of supply source. But they are also consistent with narkets being integrated -- a common world market -- but goods being imperfect substitutes so that the relative price of different suppliers can change.

Consider next a comparison of the transactions prices of tis. exports and l.S. imports in the same commodity group. There is simply overwhelming evidence that virtually without exception the dollar appreciation of the past 5 years has been accompanied by an increase in the price of exports relative to imports. Evidence in this direction comes from export-import price comparisons at the more narrow 2- and 4-digit level. An example is provided in Table 4 which shows data for two 2-digit industries.

Table 4 Cumulative Inflation: 1980:IV-1985: I

Export Prices

Non-electrical Machinery

Scientific Instruments

-------------------

Source: BLS, unpublished data

Figure $\overline{5}$ shows the ratio of export prices to import prices for telecommunications equipment and for non-electrical machninery. The figure also show the index of the nominal dollar exchange rate index. The dollar appreciation since 1980 gives rise to an increase in the relative price of exports in terms of imports. Table 5 shows indices of the relative exportimport price for all series where comparable SIC data exist. The same pattern would be obtained by comparing t.s. to German and Japanese export 
Table 5 The Ratio Export to Inport Prices

(Index 1980:1 =100)

$\begin{array}{llllllllll}7914 & 105 & 103 & n 4 & 100 & 95 & 96 & 19 & 91 & 92 \\ 81,4 & 108 & 105 & 112 & 118 & 119 & 121 & 106 & 115 & 108 \\ 8511 & 126 & 104 & 131 & 135 & 152 & 143 & 110 & 152 & 136\end{array}$

Nate the headings are SIC codes

Figure 6 The Ratio of Export to Donestic Prices

(Index 1980:4 =100)

$\begin{array}{llllllllll}79: 4 & 101 & 101 & 109 & 99 & 99 & 103 & 99 & 110 & 97 \\ 154: 4 & 100 & 104 & 91 & 100 & 100 & 103 & 103 & 93 & 99 \\ 85: 1 & 95 & 107 & 93 & 100 & 102 & 105 & 108 & 108 & 100\end{array}$

Note: The headings are SIC codes

Table 7 The Ratio of Import to Domestic Prices

(index $1980,4=100$ )

$\begin{array}{cccccccccc}7914 & 100 & 108 & 08 & 96 & 98 & 120 & 105 & 101 & 88 \\ 81: 4 & 101 & 92 & 100 & 95 & 90 & 114 & 92 & 98 & 88 \\ 85: 1 & 110 & 90 & 92 & 88 & 76 & 102 & 85 & 84 & 74\end{array}$

Note: The headings are SIC codes 
prices in these individual commodity groups. The first finding then is that across industries, virtually without exception, export prices have increased relative to import prices. This is true at the level of individial commodities but also, as we saw at the outset of the paper in Table 2, for aggregate export and import unit values.

This result would obtain strictly only in the Dixit-stiglitz model. In the other formulations it is a possibility though it need not occur. Tables 6 and 7 look at the relative price of exports and imports in terms of domestic goods. Export prices change little relative to domestic prices, even though there is no clear pattern of decline in all industries. By contrast most import prices decline in terms of domestic goods.But the order of magnitude of the decline remains relatively small compared to the change in relative unit labor costs. With a change in relative unit labor costs of more than 40 percent the decline in the relative price is in most cases less than 20 percent. That is not at all out of line with the theory once some degree of "pricing to the American market" is taking into account, just as the price setting models above suggest. It is worth noting that at the retail level this effect would obtain even more strongly. The reason is that here distribution costs cone intop play so that even with the full passthrough of cost reductions on imported goods the proportional decline in the price of imported goods would be much less than the exchange rate appreciation.

\section{Concludiug Remarks}


The models revlewed in this paper focus on a relatively short time perspective. The wage rate is assumed not to react to changes in output and profitability and the number and location of firms in an industry is unaffected. These assumptions are plausible in the short term, but it is clear that a sustained real appreciation will ultimately showe its effects in wage cuts in those industries where the loss in competitiveness causes unemployment and wage increases in the expanding sectors. Firms will close in high wage areas and entry into an industry will take place in areas where labor costs are low. These longer term adjustments are also part of the macroeconomics of adjustment to exchange rate movements. It is clear from the analysis offered here that also for these issues a microeconomic pe: spective will be helpful. In particular it will be interesting to see how pricing decisions are affected by entry and relocation possibilities at an international level and by the anticipated persistence of disequilibrium exchange rates. 
REFERENCES

Aizenman, J. (1984) "Testing Deviations from Purchasing Power Parity (PPP)." NBER Working Paper No. 1475.

(1985) "Monopolistic Competition and Deviations from PPP" Unpublished ganuscript, University of Chicago.

Blanchard, 0. (1985) "Monopolistic Competition, Small Menu Costs, and Real Effects of Nominal Money," Unpublished manuscript, MIT

Dixit, A. (1984) "International Trade Policy for Oligopolistic Industries," Economic Journal, Supplement.

and Stiglitz, J. (1977) "Monopolistic Competition and Optimum Product Diversity, "American Economic Review. June.

Dornbusch, R. (1983) "Flexible Exchange Rates and Interdependence" IMF Staff Papers, March.

(1984) "Macroeconomic Linkages between LDC.'s and the OECD Countries", unpublished manuscript presented at a World Bank Conference. (1985) "Purchasing Power Parity" NBER Working Paper No. 1591 
Giovannini, A. (1985) "Exchange Rates and Traded Goods Prices" Unpublished manuscript, Columbia University

Hart, 0. (1982) "A Model of Imperfect Competition with Keynesian Features." Quarterly Journal of Economics. February

Helpman, E. and P. Krugman (1985) Market Structure and Foreign Trade. MIT Press

Kravis, I. and R, Lipsey (1977) "Price Behavior in the Light of Balance of Payments Theories" Journal of International Economics. May (1984) "Prices and Terms of Trade for Developed Country Exports of Manufactured Goods," in Csikos-Nagy, B. et al (eds.) The Economics of Relative Prices, Saint Martin's Press, New York, 1984

Mankiw, G. (1985) "Small Menu Costs and Large Business Cycles: A Macroeconomic Model of Monopoly." Quarterly Journal of Economics. May.

Sachs, J. (1985) "The Dollar and the Policy Mix 1985" Brookings Papers, 1. and W. McKibbin (1984) "Macroeconomic Policies in the OECD and LDC's External Adjustment." Unpublished manuscript presented at a world Bank Conference. 
Salop,S.(1979) "Monopolistic Competition with Outside Goods. "The Bell Journal of Economics, Vol. 10, Spring. 